\title{
Regulation of excitatory synapses and fearful memories by stress hormones
}

\author{
Harm J. Krugers ${ }^{1}{ }^{*}$, Ming Zhou ${ }^{1}$, Marian Joëls ${ }^{1,2}$ and Merel Kindt ${ }^{3}$ \\ ${ }^{1}$ Center for Neuroscience, Swammerdam Institute for Life Sciences, University of Amsterdam, Amsterdam, Netherlands \\ ${ }^{2}$ Department of Neuroscience and Pharmacology, Rudolf Magnus Institute of Neuroscience, University Medical Center Utrecht, Utrecht, Netherlands \\ ${ }^{3}$ Department of Clinical Psychology, University of Amsterdam, Amsterdam, Netherlands
}

\section{Edited by:}

Luke R. Johnson, Uniformed Services

University of the Health Sciences,

USA

\section{Reviewed by:}

Luke R. Johnson, Uniformed Services University of the Health Sciences,

USA

Sarina Rodrigues, Oregon State

University, USA

Bruce McEwen, The Rockefeller

University, USA

\section{*Correspondence:}

Harm J. Krugers, Center for Neuroscience, Swammerdam

Institute for Life Sciences, University

of Amsterdam, Science Park 904

1098 XH, Amsterdam, Netherlands.

e-mail:h.krugers@uva.nl
Memories for emotionally arousing and fearful events are generally well retained. From the evolutionary point of view this is a highly adaptive behavioral response aimed to remember relevant information. However, fearful memories can also be inappropriately and vividly (re)expressed, such as in posttraumatic stress disorder. The memory formation of emotionally arousing events is largely modulated by hormones, peptides, and neurotransmitters which are released during and after exposure to these conditions. One of the core reactions in response to a stressful situation is the rapid activation of the autonomic nervous system, which results in the release of norepinephrine in the brain. In addition, stressful events stimulate the hypothalamus-pituitary-adrenal axis which slowly increases the release of glucocorticoid hormones from the adrenal glands. Here we will review how glucocorticoids and norepinephrine regulate the formation of fearful memories in rodents and humans and how these hormones can facilitate the storage of information by regulating excitatory synapses.

Keywords: glucocorticoids, norepinephrine, fear conditioning, AMPA

\section{INTRODUCTION}

In our daily life we face many emotionally arousing and stressful experiences, ranging from small displeasures to major life events such as accidents or loss of relatives. The perception of these events results in behavioral and physiological responses which enable adaptation to these potentially threatening situations (Chrousos, 1998; Kim and Diamond, 2002; de Kloet et al., 2005). Enhanced memory for stressful experiences is a highly adaptive behavioral response, which helps to remember relevant information (McGaugh, 2000) and prepares individuals to cope appropriately with similar events in the future (de Kloet et al., 1999).

One of the core neuro-endocrine reactions in response to a stressful situation is the rapid activation of the autonomic nervous system (ANS), which results in the release of norepinephrine in the brain, in part by neurons located in the locus coeruleus. These noradrenergic projections regulate neuronal function via $\beta$-adrenergic receptors in areas that are critically involved in learning and memory such as the hippocampus, prefrontal cortex, and amygdala (Foote et al., 1983; Gibbs and Summers, 2002; Roozendaal et al., 2009). Stressful events also stimulate activation of the hypothalamus-pituitary-adrenal (HPA) axis, which leads to a slow increase in the release of glucocorticoid hormones from the adrenal cortex (corticosterone in most rodents; cortisol in humans). These hormones enter the brain and bind to two subtypes of discretely localized receptors, i.e., the mineralocorticoid receptor (MR) and glucocorticoid receptor (GR), which (like adrenergic receptors) are expressed in regions that are critical for memory formation such as hippocampus, amygdala, and prefrontal cortex (de Kloet et al., 2005). MRs are occupied when hormone levels are low; these receptors exert their effects classically via the genome. GRs have a 10-fold lower affinity for corticosterone, become substantially activated when hormone levels rise after stress and exert slow genomic actions in cells carrying the receptor. Recent evidence has revealed that corticosteroid hormones can also regulate synaptic function via non-genomic effects, both via activation of MRs and GRs (Orchinik et al., 1991; Venero and Borrell, 1999; Di et al., 2003; Karst et al., 2005, 2010; Groc et al., 2008).

In this review we will highlight behavioral studies emphasizing how norepinephrine and glucocorticoids, via their receptors, regulate fearful memories, both in rodents and humans. Second, we will address the cellular mechanism by which norepinephrine and glucocorticoids promote learning and memory processes by focusing on regulation of excitatory synapses. Recent studies have revealed that these hormones modulate these synapses by regulating the function of AMPA type glutamate receptors (Karst et al., 2005; Hu et al., 2007; Groc et al., 2008; Martin et al., 2009; Yuen et al., 2009, 2011; Krugers et al., 2010; Liu et al., 2010; Tenorio et al., 2010), which are critically involved in synaptic transmission and activity-dependent changes in synaptic transmission - a major cellular model for learning and memory (Malinow and Malenka, 2002; Malenka, 2003; Neves et al., 2008; Kessels and Malinow, 2009; Box 1).

\section{FEAR CONDITIONING AND INHIBITORY AVOIDANCE}

Various tasks are being used to examine hormonal regulation of emotional memories. Here we will briefly address two of the most used behavioral tasks, Pavlovian fear conditioning and 


\section{Box 1 | Excitatory synapses, plasticity, and memory.}

Changes in synaptic connectivity are generally believed to underlie learning and memory processes (Doyere and Laroche, 1992; Bliss and Collingridge, 1993; Neves et al., 2008). Plasticity at synapses can be regulated at the presynaptic site (by changing the release of neurotransmitters) and/or the postsynaptic site (by changing the function and number of their receptors; Malinow and Malenka, 2002). The most explored forms of plasticity at excitatory synapses are $\mathrm{N}$-methyl-D-aspartic acid receptor (NMDAR)-dependent longterm potentiation (LTP) and long-term depression (LTD), which have been associated with changes in postsynaptic signaling (Bliss and Collingridge, 1993; Neves et al., 2008).
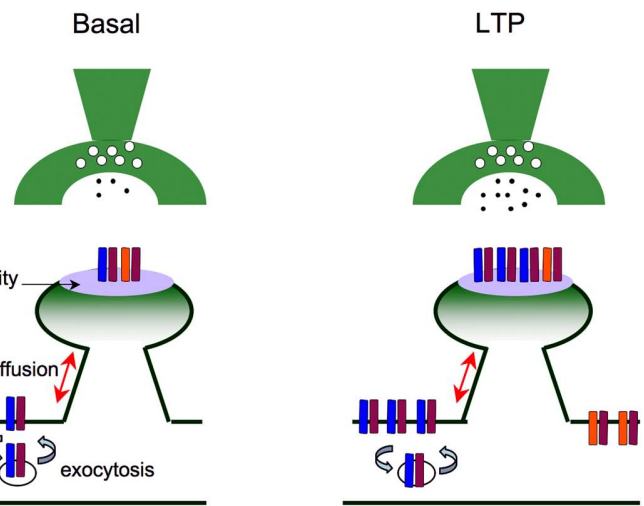

Long-term potentiation (LTP) reflects a long-lasting increase in synaptic connectivity (Neves et al., 2008) that can be experimentally elicited by high-frequency stimulation or by afferent stimulation in combination with postsynaptic depolarization (Bliss and Lomo, 1973; Bliss and Collingridge, 1993). NMDA receptors play a critical role in the induction of LTP. This receptor is a unique ligand-gated ion channels since activation requires binding of glutamate as well as membrane depolarization which is needed to release the magnesium block of the channel and to open the channel with high probability (Nowak et al., 1984). Therefore, the NMDA receptor functions as a coincidence detector that determines specificity and associativity of synaptic potentiation. Activation of NMDA receptors allows $\mathrm{Ca}^{2+}$ influx into dendritic spines of postsynaptic neurons which activates calcium-dependent enzymes, such as calcium/calmodulindependent calcium kinase II (CaMKII; Barria et al., 1997), protein kinase A (PKA; Man et al., 2007), and protein kinase C (Boehm et al., 2006). These kinases impact synaptic transmission, including regulation of the function of AMPA receptors (Lledo et al., 1995; Roche et al., 1996; Barria et al., 1997; Mammen et al., 1997; Lee et al., 2000; Boehm et al., 2006; Derkach et al., 2007). Moreover, these enzymes may help to organize structural process that leads to the incorporation of AMPA receptor-binding proteins into the postsynaptic density (PSD), followed by subsequent anchoring or additional AMPA receptors (Lisman and Zhabotinsky, 2001).

AMPA receptors are highly mobile and the link between AMPA receptor surface diffusion and cycling is evident in synaptic plasticity paradigms. Recent studies have shown that AMPA receptor trafficking is regulated by both exocytotic and endocytotic processes and by their surface lateral diffusion in the plasma membrane (Kennedy and Ehlers, 2006; Shepherd and Huganir, 2007; Newpher and Ehlers, 2008). Endocytosis of AMPA receptors is important for the number of AMPA receptors at the membrane surface and recycling endosomes supply AMPA receptors for LTP (Park et al., 2004). Receptor recycling from postsynaptic endocytic zones appears to be crucial for maintaining a mobile population of surface AMPA receptors that can be synaptically inserted to increase synaptic strength (Blanpied et al., 2002; Lu et al., 2007; Petrini et al., 2009). Together, the regulation of synaptic AMPA receptor number relies on a dynamic equilibrium between intracellular, extrasynaptic, and synaptic pools, and is regulated by the activity status of the neuronal network (Makino and Malinow, 2009; Petrini et al., 2009).

The trafficking of AMPA receptors governs rules that appear to be dependent on the subunit composition: the GluA1 carboxyl terminus mediates regulated delivery of AMPARs onto synapses upon synaptic activation while the GluA2 carboxyl terminus determines the continuous delivery of AMPARs onto synapses independent from synaptic stimulation (Shi et al., 2001). Upon LTP induction, GluA1-containing calcium-permeable AMPA receptors are incorporated into synaptic membrane, rapidly, and transiently from intracellular reserve pool (Shi et al., 2001), and are replaced by GluA1-lacking calcium-impermeable AMPA receptors shortly after LTP induction (Plant et al., 2006). Functionally, these GluA1-lacking AMPA receptors (such as GluR2/3) are calcium-impermeable (Burnashev et al., 1992; Kauer and Malenka, 2006; Plant et al., 2006) and may play a role in maintaining synaptic strength (Malinow and Malenka, 2002; Malenka, 2003; Kauer and Malenka, 2006; Plant et al., 2006). inhibitory avoidance (IA) learning. Pavlovian fear conditioning is a behavioral paradigm that can be used to study the memory formation of emotionally arousing events, both in rodent animals and humans (e.g., Nader et al., 2000; Kindt et al., 2009). In fear conditioning, an emotionally neutral conditioned stimulus (CS) such as a tone or light is paired with an aversive CS such as a foot shock unconditioned stimulus (US). After pairing, the CS elicits defensive behavior, of which freezing behavior is most frequently studied (Rodrigues et al., 2009). The amygdala is critically involved in fear conditioning (LeDoux, 2000): the lateral amygdala (LA) receives auditory, visual, olfactory, and somatosensory information from the thalamus and cortex, and plasticity in the LA is believed to underlie the association between the CS (cue) and US (Rogan et al., 1997). The hippocampus also plays a role in fear conditioning in that it provides information about the context of a fearful event (LeDoux, 2000). Finally, the medial prefrontal cortex regulates the expression and control of fear responses (LeDoux, 2000). A second task that is widely used to examine the memory formation of emotionally arousing events is IA training. In IA training, rodents are placed in a light chamber and can subsequently enter a dark chamber. Upon entry of this chamber, animals receive a footshock, which is well remembered. Inhibitory avoidance memory formation is believed to be hippocampal dependent (e.g., Whitlock et al., 2006) with the amygdala playing a modulatory role (McGaugh, 2000). In addition, regulating prefrontal cortex function by the amygdala regulates memory consolidation in this task (e.g., Barsegyan et al., 2009).

\section{NOREPINEPHRINE, GLUCOCORTICOIDS, AND FEARFUL MEMORIES IN RODENTS}

Norepinephrine and corticosteroid hormones, via their receptors, mediate (at least in part) the memory enhancing effects of stress 
and emotion (Joëls et al., 2006, 2011; Roozendaal et al., 2009). Norepinephrine enhances memory formation of emotional events via brain $\beta$-adrenergic receptors: application of norepinephrine or $\beta$ adrenergic receptor agonists promotes memory consolidation in various aversive memory tasks such as IA task, fear conditioning, and in Morris water-maze learning (Hu et al., 2007; Roozendaal et al., 2009; but see also Hatfield and McGaugh, 1999; Lee et al., 2001; Bush et al., 2010), and blocking $\beta$-adrenergic receptors reduces contextual fear memories (Ji et al., 2003). Activation of $\alpha$ adrenergic receptors also enhances memory, but presumably act by enhancing $\beta$-adrenergic actions (Ferry et al., 1999a,b). Finally, noradrenaline has been reported to enhance reconsolidation of information (e.g., Debiec and LeDoux, 2006).

Corticosteroid hormones, via MRs have been implicated in the appraisal, and response selection during the learning process (Oitzl and de Kloet, 1992; Sandi and Rose, 1994). Recent studies provide evidence that MRs are also involved in encoding of information, possibly linked to effects on appraisal, and/or response selection: application of the MR antagonist spironolactone prior to training lastingly suppress the expression of fear (Zhou et al., 2010). Moreover, genetic deletion of MRs in the forebrain led to various cognitive impairments, including impaired learning in a Morris water-maze task (Berger et al., 2006) and reduced fear learning (Zhou et al., 2010). Via GRs, corticosteroid hormones have been reported to promote long-term consolidation of information (de Kloet et al., 1999; Joëls et al., 2006; Roozendaal et al., 2009). For instance, a point mutation in the mouse GR was found to impair spatial memory formation (Oitzl et al., 2001), and blocking GRs impairs fear conditioning (Pugh et al., 1997a; Donley et al., 2005). In agreement, in several fearful learning paradigms, including fear conditioning and IA learning, post-training application of corticosterone, or GR agonists promoted the consolidation of information (Corodimas et al., 1994; Sandi and Rose, 1994; Pugh et al., 1997b; Hui et al., 2004; Roozendaal et al., 2009). These studies imply that GRs are involved in consolidation of fearful information and that genomic actions are involved. This does not exclude the possibility that other GR-dependent pathways are also involved. For instance, a recent study suggested that membrane-associated GRs also promote long-term memory in an object recognition task via chromatin modification (Roozendaal et al., 2010). Thus, it is possible that both non-genomic as well as genomic actions of corticosteroid hormones, via GRs, promote the storage of relevant information.

In addition to these well-documented effects of stress and glucocorticoids on consolidation processes, these hormones also affect memory retrieval mechanisms (de Quervain et al., 1998) and extinction processes (Brinks et al., 2009). Exposure to stress and elevated corticosteroid levels hampers the retrieval of already stored information (de Quervain et al., 1998) and glucocorticoids promote the extinction of information (de Kloet et al., 1999). Finally, blocking GRs has been reported to hamper reconsolidation of cue-conditioned fear (Pitman et al., 2011). Taken together, there is ample evidence that corticosteroid hormones, via activation of MRs and GRs, exert a repertoire of behavioral effects that promote the consolidation of relevant (fearful) information, facilitate the extinction of information that is no longer relevant, and ultimately favor behavioral adaptation (de Kloet et al., 1999).
Corticosteroids act in concert with other hormones such as norepinephrine (Roozendaal et al., 2009), endocannabinoids (Campolongo et al., 2009), corticotropin releasing hormone (CRH; Roozendaal et al., 2008) for optimal memory performance both in humans and rodents (de Quervain et al., 2009; Roozendaal et al., 2009). It is generally thought that noradrenergic activation is essential for the memory enhancing effects and that glucocorticoids play a permissive role in noradrenergic actions, thereby promoting memory formation (Hui et al., 2006; Roozendaal et al., 2006, 2009). These studies emphasize that concerted action of various stress-related mediators is required for optimal memory performance in rodents (Joëls and Baram, 2009).

\section{NOREPINEPHRINE, GLUCOCORTICOIDS, AND FEARFUL MEMORIES IN HUMANS}

The involvement of noradrenergic receptor activation in human emotional memory has been investigated by either stimulating or decreasing the release of norepinephrine (Table 1). Blocking the $\beta$-adrenergic receptors with propranolol selectively impairs memory performance for emotional arousing information (Cahill et al., 1994; Van Stegeren et al., 1998; Hurlemann et al., 2005; Van Stegeren, 2008). Conversely, adrenergic receptor agonist epinephrine (Cahill and Alkire, 2003) or the $\alpha_{2}$-adrenergic receptorantagonist yohimbine - which stimulates central noradrenergic activity by blocking the $\alpha_{2}$-adrenergic autoreceptor (Charney et al., 1987; Peskind et al., 1995) - enhances memory consolidation of emotionally arousing information (Southwick et al., 2002). These findings support that noradrenergic receptors are critically involved in the formation of human emotional memory (McGaugh, 2004).

The effect of glucocorticoids on memory formation, is typically studied by either a stress manipulation such as the Trier Social Stress Test (TSST; Kirschbaum et al., 1993), the cold pressor test (CPT), or by administering cortisol directly. Although stress or cortisol treatment generally impairs memory retrieval (de Quervain et al., 2000), the same hormone has been reported to enhance memory consolidation (Het et al., 2005; Wolf, 2009). These memory effects of the corticosteroids are often stronger for emotional arousing material (Wolf, 2009).

Even though the memory enhancing effects of emotional arousal are extremely functional from an evolutionary perspective, the impact of emotion on memory can also have long-term detrimental consequences. Research into the effects of stress on emotional memory is highly relevant for a better understanding

\section{Table 1 | Role noradrenergic hormones in emotional memories.}

Enhanced noradrenergic tone

\begin{tabular}{lrl}
\hline Emotional memory formation & $\uparrow$ & Cahill et al. (1994); Van Stegeren et al. \\
& (1998); Van Stegeren (2008); Peskind \\
& et al. (1995); Southwick et al. (2002); \\
& Soeter and Kindt (2011a) \\
Extinction fear conditioning & $\downarrow$ & Soeter and Kindt (2011a) \\
Reconsolidation fear & $\uparrow$ & Kindt et al. (2009); Soeter and Kindt \\
& & $(2010)$ \\
Fear generalization & $\uparrow$ & Soeter and Kindt (2011a)
\end{tabular}


of the etiology and maintenance of emotional disorders, such as anxiety disorders. In humans the effects of stress on memory are traditionally investigated for non-associative and distinct emotional stimuli such as emotional stories and pictures (McGaugh, 2004; Wolf, 2009). Given that patients with anxiety disorders either fear for stimuli that are intrinsically non-threatening or they persist in fear responding whilst the acute threat already disappeared (e.g., after traumatic experiences), the emotional memory literature seems to be inconclusive for the understanding of these disorders. Indeed, an important aspect of the pathogenesis of anxiety disorders is that they originate from a learned association between a previously neutral event (CS; such as a stranger) and an anticipated disaster (US; such as physical assault). This can be experimentally modeled in a differential human fear conditioning paradigm. In contrast to animal research, the effect of stress hormones such as noradrenaline on associative fear memory is not extensively studied in humans.

Another notable aspect of research into human emotional memory is that most studies did not assess the emotional response but the declarative memory for the emotional stimuli. However, not the factual recollection but the concomitant excessive emotional expression is the main problem in emotional disorders (Ehlers et al., 2004). In particular, hyper-noradrenergic activity in the wake of a life-threatening event may contribute to the "overconsolidation" of memory for trauma, generating disturbing intrusive memories that are characteristic of posttraumatic stress disorder (PTSD; Pitman and Delahanty, 2005; Glannon, 2006; Henry et al., 2007). In patients with PTSD, these involuntary traumatic memories may be experienced as reenactments of the original trauma ("flashbacks") and are associated with significant emotion and distress (DSM-IV-R; American Psychiatric Association, 2000).

In two human fear conditioning studies, we recently demonstrated that the systemic administration of the $\alpha_{2}$-adrenergic receptor-antagonist yohimbine $(20 \mathrm{mg})$ during memory formation strengthened the later expression of human associative fear memory (fear potentiated startle reflex; Soeter and Kindt, 2011a,c). More specifically, stimulation of the noradrenergic system by the administration of yohimbine during memory formation did not directly augment the differential startle fear response. Yet, the retention tests presented $48 \mathrm{~h}$ later uncovered that the earlier administration of yohimbine extensively delayed the process of extinction learning and generated a superior recovery of fear (reinstatement and reacquisition). The competition between the original excitatory fear association and the newly formed inhibitory memory trace determines the behavioral outcome of extinction learning (Bouton, 1993). Given that yohimbine was administered during fear conditioning ( $48 \mathrm{~h}$ prior to fear extinction), the noradrenergic manipulation apparently delayed the process of extinction by strengthening the original excitatory fear association. In addition, the yohimbine administration promoted fear generalization, a core feature of anxiety disorders (Soeter and Kindt, 2011c). In rodents, the generalization of fear seems to be dependent on the strength of the memory as operationalized by training intensity (both US intensity and the number of CS+ and US applied; Laxmi et al., 2003). Allegedly, the strengthening of a specific fear memory trace by $\alpha_{2}$-adrenergic receptor-manipulation may produce fear generalization similar to training intensity.

The effect of $\beta$-adrenergic interference has not yet been demonstrated for the consolidation of associative fear memory. For reconsolidation, however, a series of studies showed a robust memory impairing effect of the $\beta$-adrenergic receptor blocker propranolol (Kindt et al., 2009; Soeter and Kindt, 2010, 2011b,c). Disrupting reconsolidation by propranolol ( $40 \mathrm{mg}$ ) - administered before or after memory retrieval - "deleted" the emotional expression of a fear memory in humans (Kindt et al., 2009; Soeter and Kindt, $2010,2011 b, c)$. The anxiolytic properties of propranolol could not explain the fear erasure, as omission of memory reactivation after propranolol intake yielded intact fear responding. Together, these recent studies illustrate the involvement of noradrenergic modulation in the (re)consolidation and generalization of human associative fear memory. Given that fear generalization is a main characteristic of anxiety disorders, these findings suggest that norepinephrine may play an important role in the etiology and maintenance of anxiety disorders.

In contrast to the noradrenergic modulation of associative fear memory, the modulatory role of cortisol seems to be more complex. A mixture of fear conditioning paradigms reveals ambiguous findings regarding the effect of cortisol on the emotional expression of associative fear memory in humans. Cue or context fear conditioning and eyeblink conditioning studies - using either a trace or delay reinforcement scheme - have shown impairing as well as enhancing effects of cortisol on associative fear memory. First, a relatively low dose of hydrocortisone $(30 \mathrm{mg})$ affected cue fear conditioning, decreasing it in men and increasing it in women (Stark et al., 2006; Merz et al., 2010; Tabbert et al., 2010). In contrast to this gender effect, exposure to a stress manipulation (elevating both the sympathetic and the glucocorticoid stress response) facilitated cue fear conditioning in men but not in women (Zorawski et al., 2005, 2006; Jackson et al., 2006). Furthermore, a high dose of hydrocortisone $(60 \mathrm{mg})$ exclusively enhanced context fear conditioning in both sexes, while leaving cue fear conditioning unaffected (Grillon et al., 2011). Finally, delay eyeblink conditioning is impaired in men and women after a stress manipulation (TSST; Wolf et al., 2009), whereas trace eyeblink conditioning is improved by a stress manipulation (CPT; Duncko et al., 2007) as well as by cortisol ( $2 \mathrm{mg}$, administered intravenously; Kuehl et al., 2010), but also by a cortisol inhibitor (1500 mg metyrapone; Nees et al., 2008). In summary, future research is required to clarify the modulatory role of cortisol on associative fear memory in humans and the possible interaction with the noradrenergic system.

\section{EXCITATORY SYNAPSES AND LEARNING AND MEMORY}

An import question that remains to be addressed is which mechanisms are involved in the effects of norepinephrine and glucocorticoids on fear learning. The current view of how memories are formed is that neurons are activated during the learning process thereby changing synaptic communication (Neves et al., 2008). AMPA ( $\alpha$-amino-3-hydroxy-5-methyl-4-isoxazole propionate) type glutamate receptors mediate most of the fast excitatory synaptic transmission in the brain and controlling the number of synaptic AMPA receptors on the postsynaptic membrane is an 
essential mechanism to regulate synaptic transmission and plasticity (Malinow and Malenka, 2002; Plant et al., 2006; Kessels and Malinow, 2009). The best-studied forms of synaptic plasticity are long-term potentiation (LTP) and long-term depression (LTD) of excitatory synaptic transmission (Malinow and Malenka, 2002; Bredt and Nicoll, 2003). LTP involves the activity-dependent recruitment of AMPA receptors to the postsynaptic membrane and a concurrent increase in AMPA-mediated transmission whereas LTD reflects a decrease in synaptic AMPA receptor function.

AMPA receptors are heteromeric tetramer complexes formed of different combinations of GluA1, GluA2, GluA3, and GluA4 subunits (Keinanen et al., 1990; Tanabe et al., 1992; Wisden and Seeburg, 1993; Hollmann and Heinemann, 1994; Wenthold et al., 1996). In adult hippocampal pyramidal neurons, two main populations of AMPA receptor complexes are found: GluA1/GluA2 and GluA2/GluA3 containing AMPA receptors. The trafficking of AMPA receptors to and from the synapse is regulated by (1) exocytotic/endocytotic recycling between intracellular and membrane receptor pools (Passafaro et al., 2001; Gerges et al., 2006); and (2) surface diffusion between extrasynaptic and synaptic receptor pools (Adesnik et al., 2005; Ashby et al., 2006; Ehlers et al., 2007; Makino and Malinow, 2009; Petrini et al., 2009; Box 1). The leading model for constitutive and activity-dependent AMPA receptor trafficking is that activity-dependent processes (such as induction of LTP) promote synaptic delivery of GluA1-containing AMPA receptors which are believed to be gradually replaced by the cycling GluA2/GluA3 heteromers after LTP induction (Shi et al., 2001; Plant et al., 2006).

AMPA receptors have been shown to underlie memory formation. Inhibitory avoidance training rapidly (and reversibly) increases hippocampal synaptic insertion of GluA1 and GluA2 AMPA receptor subunits (Whitlock et al., 2006). Studies using mutant mice reveal that GluA1 mutant mice are hampered in short-term memory processes (Reisel et al., 2002; Schmitt et al., 2005; Sanderson et al., 2007, 2009, 2011), while the mutation leaves Morris water-maze spatial navigation unaffected (Zamanillo et al., 1999). Moreover, GluA2 mutant mice are impaired in a spatial working memory task and elevated Y-maze (Shimshek et al., 2006). These studies indicate that GluA1 and GluA2 subunits are at least relevant for short-term memory processes. Finally, the observation that preventing synaptic insertion of GluAl-containing AMPA receptors in the amygdala hampers tone-cue fear conditioning implies that trafficking of GluA1-containing AMPA receptors is critical for fear learning (Rumpel et al., 2005).

\section{STRESS HORMONES AND HIPPOCAMPAL EXCITATORY SYNAPSES}

The cellular mechanisms via which norepinephrine and corticosterone facilitate learning and memory processes are starting to be unraveled. Here we summarize studies - mainly in the rodent hippocampus - that have examined how these hormones regulate synaptic transmission and synaptic plasticity. Recent studies have revealed that AMPA receptors are regulated by norepinephrine and glucocorticoid hormones. Via activation of $\beta$-adrenergic receptors, norepinephrine can rapidly - but reversibly - activate PKA and CaMKII (Wang et al., 2004; Hu et al., 2007) and increase the phosphorylation of GluA1 at Ser845 and Ser831. Likewise, stress, via activation of $\beta$-ARs increases phosphorylation of Ser831 and Ser845 (Hu et al., 2007). In agreement with the observations that phosphorylation of AMPA receptors at these sites is critical for LTP, activation of $\beta$-adrenergic receptors facilitates the induction of hippocampal (LTP; Thomas et al., 1996; Winder et al., 1999; Hu et al., 2007; Tenorio et al., 2010) and enhances activity-dependent synaptic insertion of AMPA receptors (Hu et al., 2007). Interestingly, activation of $\beta$-adrenergic receptors facilitates LTP in a time-dependent manner; these receptors only facilitate LTP when these receptors are activated during and shortly after induction of LTP, i.e., when the adrenergic receptors enhance phosphorylation of GluA1 (Hu et al., 2007).

Also corticosteroid hormones can rapidly and reversibly promote hippocampal synaptic transmission. Within minutes after application, glucocorticoids increase synaptic transmission in the hippocampus (Karst et al., 2005), via activation of low affinity MRs which are located in the cellular membrane. This rapid and reversible increase in synaptic transmission after glucocorticoid exposure most likely results from an increase in the presynaptic release of glutamate (Karst et al., 2005) in which the Erk pathway is critically involved (Olijslagers et al., 2008). At the same time scale, glucocorticoid exposure, via membrane MRs rapidly increases the lateral diffusion of GluA1 and GluA2 subunits, without altering the number of postsynaptic AMPA receptors (Groc et al., 2008; Martin et al., 2009). At this time, glucocorticoids, via MRs, promote the activity-dependent synaptic insertion of GluA2-containing AMPA receptors (Groc et al., 2008). Finally, glucocorticoids also facilitate LTP in at time-dependent manner; LTP is only facilitated when elevated corticosteroid levels are present at the moment of highfrequency stimulation (Wiegert et al., 2006). These studies show that both norepinephrine and glucocorticoids can rapidly facilitate synaptic plasticity and thereby increase the ability to encode information at the cellular level (Figure 1). While glucocorticoids and norepinephrine act in concert for optimal memory performance, they also affect synaptic function in a synergistic fashion (Joëls et al., 2011). Application of a $\beta$-adrenergic receptor agonist together with corticosterone facilitates the induction of LTP in the hippocampus (Pu et al., 2007). Moreover, activation of $\beta$ adrenergic receptors together with corticosterone enhances AMPA receptor function (Zhou et al., 2011).

After exposure to a stressful event, plasma corticosteroid levels slowly return to their pre-stress level in about 2 hours (de Kloet et al., 2005). Nevertheless, these hormones exert - via a slow, genomic mode of action - long-lasting effects on excitatory synapses (Figure 1). Elevated glucocorticoid levels increase the membrane expression and synaptic insertion of GluA2-containing AMPA receptors in the hippocampal neurons (Groc et al., 2008; Martin et al., 2009). These effects are mediated via GRs, require time as well as the synthesis of new proteins, and most likely result from increased lateral diffusion and/or altered ratio of endocytosis/exocytosis of GluA2-containing AMPA receptors (Groc et al., 2008; Martin et al., 2009). Functionally, glucocorticoids also slowly increase the amplitude of evoked as well as spontaneous AMPA receptor-mediated synaptic currents in hippocampal primary cultures and hippocampal slices (Karst and Joëls, 2005; Martin et al., 2009), thereby enhancing AMPA receptor-mediated 


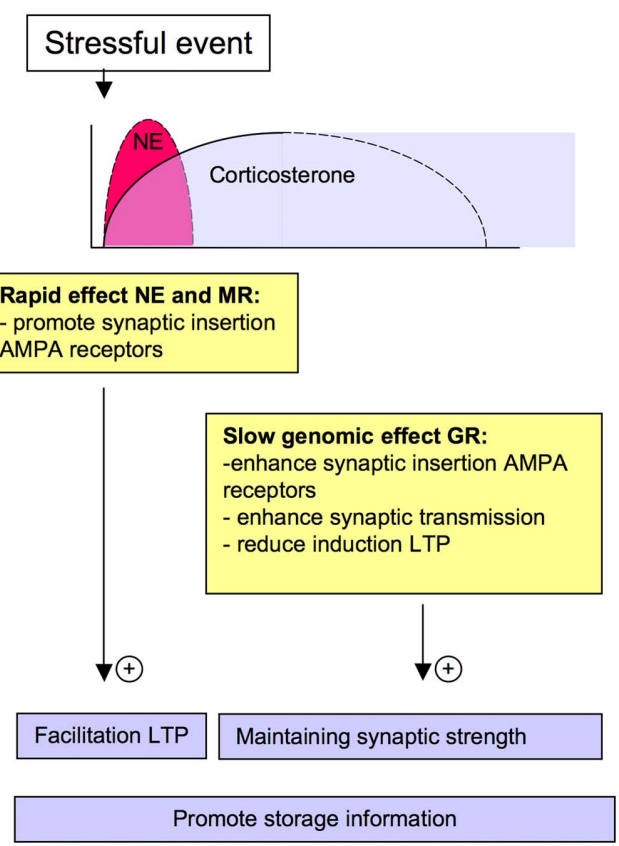

FIGURE 1 | Norepinephrine and glucocorticoids rapidly increase activity-dependent synaptic insertion of AMPA receptors. Slowly, corticosteroid hormones enhance AMPA receptor mediated synaptic transmission and reduce the ability to encode novel information. This might preserve and promote the retention of the original (fearful and relevant) memory trace (see text for details)

synaptic transmission. Furthermore, glucocorticoids - via a slow mode of action - suppress the induction of LTP (Alfarez et al., 2002; Wiegert et al., 2005), facilitate LTD (Coussens et al., 1997; $\mathrm{Xu}$ et al., 1997) and increase endocytosis of synaptic AMPARs upon stimuli that weaken synaptic transmission (Martin et al., 2009).

\section{STRESS HORMONES: FROM EXCITATORY SYNAPSES TO FEARFUL MEMORIES}

The release of norepinephrine and glucocorticoids promotes the consolidation of fearful memories in rodents and humans (Roozendaal et al., 2009). Recent findings indicate that stress hormones like norepinephrine and corticosterone both rapidly and slowly increase AMPA receptor mediated synaptic transmission. These differential effects on AMPA receptor trafficking may provide a cellular mechanism that underlies the memory enhancing effects of these hormones. Initially glucocorticoids and norepinephrine promote the AMPA receptor mediated synaptic transmission and synaptic insertion of AMPA receptors (Karst et al., 2005; Hu et al., 2007; Groc et al., 2008; Olijslagers et al., 2008). These effects are accompanied by an increased ability to elicit LTP (Thomas et al., 1996; Winder et al., 1999; Wiegert et al., 2006; Hu et al., 2007) and may therefore contribute to an enhanced capacity to acquire and store information (Figure 1).

Next, glucocorticoids via a slow genomic action enhance synaptic insertion of AMPA receptors. At the same time, glucocorticoids suppress activity-dependent increase in synaptic AMPA receptors
(Groc et al., 2008), activity-dependent increase in AMPA receptormediated synaptic transmission (Hui Xiong, unpublished observations), and synaptic plasticity (e.g., Wiegert et al., 2005). Thus, these hormones slowly reduce the ability to encode novel information. The consequence could be that these hormones also prevent the ability to overwrite information that is present in the network, in a meta-plastic manner (Joëls et al., 2006; Krugers et al., 2010), thereby preserving the original memory trace. Furthermore, glucocorticoids promote the loss of synaptic AMPA receptors which is enhanced upon stimuli that reduce synaptic transmission (Martin et al., 2009), thereby accentuating synaptic efficacy. This provides a picture where glucocorticoids, via MRs, and $\beta$-adrenergic receptor activation rapidly enhance the ability to store information, which is consolidated and accentuated via activation of GRs (Krugers et al., 2010; Figure 1).

\section{FUTURE PERSPECTIVES}

There are a number of relevant issues which need to be addressed:

(1) First, it is unknown how activation of MRs and GRs enhance (activity-dependent) synaptic insertion of AMPA receptors. Potential candidates are enzymes that regulate the phosphorylation of AMPA receptors, regulators of endocytosis/exocytosis (Liu et al., 2010), and/or proteins that promote transport and synaptic retention of AMPA receptors (Nicoll et al., 2006).

(2) A behaviorally very relevant question is whether AMPA receptors mediate the memory enhancing effects of stress hormones. Studies using mice carrying mutations in the GluR1 phosphorylation sites indicate that norepinephrine-regulated phosphorylation of GluR1 facilitates emotional memory (Hu et al., 2007). Moreover, application of pep2m, which blocks trafficking of GluA2-containing AMPA receptors also prevents the memory enhancing effects of stress (Conboy and Sandi, 2010), and fearful memories (Migues et al., 2010). Also, stress-induced regulation of Rab4/SGK may underlie stress-effects on AMPA receptor function and stress-effects on working memory (Yuen et al., 2011). Studies using temporal erasure of functional AMPA receptors will be required to reveal whether regulation of AMPA receptor function is critical for stress-induced facilitation of the different learning phases (such as acquisition and/or consolidation of information).

(3) The studies carried out so far mainly focused on the hippocampal formation. However, region-specific effects of stress hormones on excitatory synapses - even in the hippocampus need to be considered. For example, in an elegant series of studies it was shown that corticosteroid hormones may have different effects on synaptic plasticity within the hippocampal formation; corticosteroid hormones suppress synaptic plasticity in de dorsal hippocampus but enhance synaptic plasticity in the ventral hippocampus (Maggio and Segal, 2007, 2009; Segal et al., 2010).

Moreover, other brain areas such as prefrontal cortex and amygdala are also critically involved in the regulation of fearful memories. It will therefore also be necessary to carefully investigate the effects of stress hormones on excitatory synapses in 
these brain areas. Indeed corticosteroid hormones have been reported to affect AMPA receptor mediated synaptic transmission in the amygdala (Karst et al., 2010) differently from the hippocampus (see Karst et al., 2005), and stress and corticosteroid hormones regulate AMPA receptors (Yuen et al., 2011) and function of the prefrontal cortex (Arnsten, 2009).

(4) Behaviorally, several neurotransmitters (e.g., norepinephrine, enodocannabinoids, dopamine), neuropeptides, and steroid hormones (e.g., corticosteroid hormones; Joëls and Baram, 2009) may act together for optimal memory performance (de Quervain et al., 2009; Roozendaal et al., 2009) and cellular plasticity ( $\mathrm{Pu}$ et al., 2007). It will therefore be relevant to examine whether and how these stress-mediators interact to regulate AMPA receptor function as well as learning and memory.

(5) In susceptible individuals, memories for aversive events may remain inappropriately present and lead to anxiety disorders such as in (PTSD; de Kloet et al., 2005). This underscores the importance of understanding how individual differences in cognitive development, and the ability to cope with threatening events later in life, are determined. These differences are largely regulated by environmental factors, in particular during the early postnatal period - in conjunction with genetic factors - (Hackman et al., 2010). When comparing rodent offspring of mothers that exhibited low levels of maternal care with the adult offspring of mothers that exhibited high levels of maternal care, enhanced memories for fearful events and increased anxiety was observed (Weaver et al., 2006; Champagne et al., 2008). Also, mater-

\section{REFERENCES}

Abrari, K., Rashidy-Pour, A., Semnanian, S., and Fathollahi, Y. (2008). Administration of corticosterone after memory reactivation disrupts subsequent retrieval of a contextual conditioned fear memory: dependence upon training intensity. Neurobiol. Learn. Mem. 89, 178-184.

Adesnik, H., Nicoll, R. A., and England, P. M. (2005). Photoinactivation of native AMPA receptors reveals their real-time trafficking. Neuron 48, 977-985.

Alfarez, D. N., Wiegert, O., Joëls, M., and Krugers, H. J. (2002). Corticosterone and stress reduce synaptic potentiation in mouse hippocampal slices with mild stimulation. Neuroscience 115, 1119-1126.

American Psychiatric Association. (2000). Diagnostic and Statistical Manual of Mental Disorders, 4th Edn, Text Revision (DSM-IVTR). Washington, DC: American Psychiatric Association.

Arnsten, A. F. (2009). Stress signalling pathways that impair prefrontal cortex structure and function. Nat. Rev. Neurosci. 10, 410-422.
Ashby, M. C., Maier, S. R., Nishimune, A., and Henley, J. M. (2006). Lateral diffusion drives constitutive exchange of AMPA receptors at dendritic spines and is regulated by spine morphology. J. Neurosci. 26, 7046-7055.

Barrett, D., and Gonzalez-Lima, F. (2004). Behavioral effects of metyrapone on Pavlovian extinction. Neurosci. Lett. 371, 91-96.

Barria, A., Muller, D., Derkach, V., Griffith, L. C., and Soderling, T. R. (1997). Regulatory phosphorylation of AMPA-type glutamate receptors by CaM-KII during longterm potentiation. Science 276, 2042-2045.

Barsegyan, A., Mackenzie, S. M., Kurose, B. D., McGaugh, J. L., and Roozendaal, B. (2009). Glucocorticoids in the prefrontal cortex enhance memory consolidation and impair working memory by a common neural mechanism. Proc. Natl. Acad. Sci. U.S.A. 107, 16655-16660.

Berger, S., Wolfer, D. P., Selbach, O., Alter, H., Erdmann, G., Reichardt, H. M., Chepkova, A. N., Welzl, H., Haas, H. L., Lipp, H. P., and Schutz,

nal deprivation results in enhanced fear learning (Oomen et al., 2010). It will therefore be important to examine how stress hormones promote the retention of stressful memories and regulate molecular mechanisms that are fundamental for learning and memory (such as AMPA receptors) in individuals who suffered from negative early life experiences.

(6) Finally, studies over the past decade have shown that stored memories are rendered labile after being retrieved, and require de novo protein synthesis for reconsolidation (Nader et al., 2000). Reconsolidation has been demonstrated in various tasks and species (Nader et al., 2000; Eisenberg et al., 2003; Sangha et al., 2003), including humans (Kindt et al., 2009; Schiller et al., 2010). The notion that stored memories can be turned into a labile state has opened new avenues to reduce the expression of fear more permanently than the traditional extinction procedure (Pitman and Delahanty, 2005), e.g., by targeting noradrenergic receptors (Pitman et al., 2002; Orr et al., 2006; Brunet et al., 2008; Kindt et al., 2009; Soeter and Kindt, 2010, 2011b,c) and corticosteroid receptors (Barrett and Gonzalez-Lima, 2004; Cai et al., 2006; Abrari et al., 2008). Future studies will be needed to test whether targeting stress hormones and their receptors can be used to effectively reduce fear and whether these fear-reducing effects are mediated via AMPA receptors (Clem and Huganir, 2010).

\section{ACKNOWLEDGMENTS}

The authors are supported by a special grant from the Cognitive Science Center Amsterdam (CSCA).

G. (2006). Loss of the limbic mineralocorticoid receptor impairs behavioral plasticity. Proc. Natl. Acad. Sci. U.S.A. 103, 185-200.

Blanpied, T. A., Scott, D. B., and Ehlers, M. D. (2002). Dynamics and regulation of clathrin coats at specialized endocytic zones of dendrites and spines. Neuron 36, 435-449.

Bliss, T. V., and Collingridge, G. L. (1993). A synaptic model of memory: long-term potentiation in the hippocampus. Nature 361, 31-39.

Bliss, T. V., and Lomo, T. (1973). Long-lasting potentiation of synaptic transmission in the dentate area of the anaesthetized rabbit following stimulation of the perforant path. J. Physiol. 232, 331-356.

Boehm, J., Kang, M. G., Johnson, R. C., Esteban, J., Huganir, R. L., and Malinow, R. (2006). Synaptic incorporation of AMPA receptors during LTP is controlled by a PKC phosphorylation site on GluR1. Neuron 51, 213-225.

Bouton, M. E. (1993). Context, time, and memory retrieval in the interference paradigm of Pavlovian learning. Psychol. Bull. 114, 80-99.
Bredt, D. S., and Nicoll, R. A. (2003) AMPA receptor trafficking at excitatory synapses. Neuron 40, 361-379.

Brinks, V., de Kloet, E. R., and Oitzl, M. S. (2009). Corticosterone facilitates extinction of fear memory in $\mathrm{BALB} / \mathrm{c}$ mice but strengthens cue related fear in C57BL/6 mice. Exp. Neurol. 216, 375-382.

Brunet, A., Orr, S. P., Tremblay, J., Robertson, K., Nader, K., and Pitman, R. K. (2008). Effect of post-retrieval propranolol on psychophysiologic responding during subsequent script-driven traumatic imagery in post-traumatic stress disorder. J. Psychiatr. Res. 42, 503-506.

Burnashev, N., Monyer, H., Seeburg, P. H., and Sakmann, B. (1992). Divalent ion permeability of AMPA receptor channels is dominated by the edited form of a single subunit. Neuron 8, 189-198.

Bush, D. E. A., Caparosa, E. M., Gekker, A., and LeDoux, J. E. (2010). Betaadrenergic receptors in the lateral nucleus of the amygdala contribute to the acquisition but not the consolidation of auditory fear conditioning. Front. Behav. Neurosci. 4:1-7. doi: 10.3389/fnbeh.2010.00154 
Cahill, L., and Alkire, M. T. (2003). Epinephrine enhancement of human memory consolidation: interaction with arousal at encoding. Neurobiol. Learn. Mem. 79, 194-198.

Cahill, L., Prins, B., Weber, M., and McGaugh, J. L. (1994). Betaadrenergic activation and memory for emotional events. Nature 371, 702-704.

Cai, W. H., Blundell, J., Han, J., Greene, R. W., and Powell, C. M. (2006). Postreactivation glucocorticoids impair recall of established fear memory. J. Neurosci. 26, 9560-9566.

Campolongo, P., Roozendaal, B., Trezza, V., Hauer, D., Schelling, G., McGaugh, J. L., and Cuomo, V. (2009). Endocannabinoids in the rat basolateral amygdala enhance memory consolidation and enable glucocorticoid modulation of memory. Proc. Natl. Acad. Sci. U.S.A. 106, 4888-4893.

Champagne, D. L., Bagot, R. C., van Hasselt, F., Ramakers, G., Meaney, M. J., de Kloet, E. R., Joëls, M., and Krugers, H. (2008). Maternal care and hippocampal plasticity: evidence for experience-dependent structural plasticity, altered synaptic functioning, and differential responsiveness to glucocorticoids and stress. J. Neurosci. 28, 6037-6045.

Charney, D. S., Woods, S. W., Goodman, W. K., and Heninger, G. R. (1987). Neurobiological mechanisms of panic-anxiety: biochemical and behavioural correlates of yohimbine-induced panic attacks. Am. J. Psychiatry 44, 1030-1036.

Chrousos, G. P. (1998). Stressors, stress, and neuroendocrine integration of the adaptive response. The 1997 Hans Selye memorial lecture. Ann. N. Y. Acad. Sci. 851, 311-335.

Clem, R. L., and Huganir, R. L. (2010). Calcium-permeable AMPA receptor dynamics mediate fear memory erasure. Science 330, 1108-1112.

Conboy, L., and Sandi, C. (2010). Stress at learning facilitates memory formation by regulating AMPA receptor trafficking through a glucocorticoid action. Neuropsychopharmacology 35 , 674-685.

Corodimas, K. P., LeDoux, J. E., Gold, P. W., and Schulkin, J. (1994). Corticosterone potentiation of conditioned fear in rats. Ann. N. Y. Acad. Sci. 746, 392-393.

Coussens, C. M., Kerr, D. S., and Abraham, W. C. (1997). Glucocorticoid receptor activation lowers the threshold for NMDAreceptor-dependent homosynaptic long-term depression in the hippocampus through activation of voltage-dependent calcium channels. J. Neurophysiol. 78, 1-9.

de Kloet, E. R., Joëls, M., and Holsboer, F. (2005). Stress and the brain: from adaptation to disease. Nat. Rev. Neurosci. 6, 463-475.

de Kloet, E. R., Oitzl, M. S., and Joels, M. (1999). Stress and cognition: are corticosteroids good or bad guys? Trends Neurosci. 22, 422-426.

de Quervain, D. J., Aerni, A., Schelling, G., and Roozendaal, B. (2009). Glucocorticoids and the regulation of memory in health and disease. Front. Neuroendocrinol. 30, 358-370.

de Quervain, D. J., Roozendaal, B., and McGaugh, J. L. (1998). Stress and glucocorticoids impair retrieval of long-term spatial memory. Nature 394, 787-790.

de Quervain, D. J., Roozendaal, B., Nitsch, R. M., McGaugh, J. L., and Hock, C. (2000). Acute cortisone administration impairs retrieval of long-term declarative memory in humans. Nat. Neurosci. 3, 313-314.

Debiec, J., and LeDoux, J. E. (2006). Noradrenergic signaling in the amygdala contributes to the reconsolidation of fear memory: treatment implications for PTSD. Ann. N. Y. Acad. Sci. 1071, 521-524.

Derkach, V. A., Oh, M. C., Guire, E. S., and Soderling, T. R. (2007). Regulatory mechanisms of AMPA receptors in synaptic plasticity. Nat. Rev. Neurosci. 8, 101-113.

Di, S., Malcher-Lopes, R., Halmos, K. C., and Tasker, J. G. (2003). Nongenomic glucocorticoid inhibition via endocannabinoid release in the hypothalamus: a fast feedback mechanism. J. Neurosci. 23, 4850-4857.

Donley, M. P., Schulkin, J., and Rosen, J. B. (2005). Glucocorticoid receptor antagonism in the basolateral amygdala and ventral hippocampus interferes with long-term memory of contextual fear. Behav. Brain Res. 164, 197-205.

Doyere, V., and Laroche, S. (1992). Linear relationship between the maintenance of hippocampal long-term potentiation and retention of an associative memory. Hippocampus 2 , 39-48.

Duncko, R., Cornwell, B., Cui, L., Merikangas, K. R., and Grillon, C. (2007). Acute exposure to stress improves performance in trace eyeblink conditioning and spatai learning tasks in healthy men. Learn. Mem. 14, 329-335.

Ehlers, A., Hackmann, A., and Michael, T. (2004). Intrusive re-experiencing in post-traumatic stress disorder: phenomenology, theory, and therapy. Memory 12, 403-415.
Ehlers, M. D., Heine, M., Groc, L., Lee M. C., and Choquet, D. (2007). Diffusional trapping of GluR1 AMPA receptors by input-specific synaptic activity. Neuron $54,447-460$.

Eisenberg, M., Kobilo, T., Berman, D. E., and Dudai, Y. (2003). Stability of retrieved memory: inverse correlation with trace dominance. Science 301, 1102-1104.

Ferry, B., Roozendaal, B., and McGaugh, J. L. (1999a). Basolateral amygdala noradrenergic influences on memory storage are mediated by an interaction between beta- and alpha1-adrenoceptors. J. Neurosci. 19, 5119-5123.

Ferry, B., Roozendaal, B., and McGaugh, J. L. (1999b). Involvement of alpha1adrenoceptors in the basolateral amygdala in modulation of memory storage. Eur. J. Pharmacol. 372, 9-16.

Foote, S. L., Bloom, F. E., and AstonJones, G. (1983). Nucleus locus ceruleus: new evidence of anatomical and physiological specificity. Physiol. Rev. 63, 844-914.

Gerges, N. Z., Backos, D. S., Rupasinghe, C. N., Spaller, M. R., and Esteban, J. A. (2006). Dual role of the exocyst in AMPA receptor targeting and insertion into the postsynaptic membrane. EMBO J. 25 , 1623-1634.

Gibbs, M. E., and Summers, R. J. (2002). Role of adrenoceptor subtypes in memory consolidation. Prog. Neurobiol. 67, 345-391.

Glannon, W. (2006). Psychopharmacology and memory. J. Med. Ethics 32 , 74-78.

Grillon, C., Heller, R., Hirschhorn, E. Kling, M. A., Pine, D. S., Schulkin, J. and Vythilingam, M. (2011). Acute hydrocortisone treatment increases anxiety but not fear in healthy volunteers: a fear-potentiated startle study. Biol. Psychiatry 69, 549-555.

Groc, L., Choquet, D., and Chaouloff, F. (2008). The stress hormone corticosterone conditions AMPAR surface trafficking and synaptic potentiation. Nat. Neurosci. 11, 868-870.

Hackman, D. A., Farah, M. J., and Meaney, M. J. (2010). Socioeconomic status and the brain: mechanistic insights from human and animal research. Nat. Rev. Neurosci. 11 651-659.

Hatfield, T., and McGaugh, J. L. (1999). Norepinephrine infused into the basolateral amygdala posttraining enhances retention in a spatial water maze task. Neurobiol. Learn. Mem. 71, 232-239.

Henry, M., Fishman, J. R., and Youngner, S. J. (2007). Propranolol and the prevention of post-traumatic stress disorder: is it wrong to erase the "sting" of bad memories? Am. J. Bioeth. 7, 12-20.

Het, S., Ramlow, G., and Wolf, O. T. (2005). A meta-analytic review of the effects of acute cortisol administration on human memory. Psy choneuroendocrinology 30, 771-784.

Hollmann, M., and Heinemann, S. (1994). Cloned glutamate receptors. Annu. Rev. Neurosci. 17, 31-108.

Hu, H., Real, E., Takamiya, K., Kang, M., Ledoux, J. E., Huganir, R. L., and Malinow, R. (2007). Emotion enhances learning via norepinephrine regulation of AMPA-Receptor trafficking. Cell 131, 160-173.

Hui, G. K., Figueroa, I. R., Poytress, B. S., Roozendaal, B., McGaugh, J. L., and Weinberger, N. M. (2004). Memory enhancement of classical fear conditioning by post-training injections of corticosterone in rats. Neurobiol. Learn. Mem. 81, 67-74.

Hui, I. R., Hui, G. K., Roozendaal, B., McGaugh, J. L., and Weinberger, N. M. (2006). Posttraining handling facilitates memory for auditory-cue fear conditioning in rats. Neurobiol. Learn. Mem. 86, 160-163.

Hurlemann, R., Hawellek, B., Matusch, A., Kolshc, H., Wollersen, H., Madea B., Vogeley, K., Maier, W., and Dolan, R. J. (2005). Noradrenergic modulation of emotion-induced forgetting and remembering. J. Neurosci. 25, 6343-6349.

Jackson, E. D., Payne, J. D., Nadel, L., and Jacobs, W. J. (2006). Stress differentially modulates fear conditioning in healthy men and women. Biol. Psychiatry 59, 516-522.

Ji, J. Z., Wang, X. M., and Li, B. M. (2003). Deficit in long-term contextual fear memory induced by blockade of betaadrenoceptors in hippocampal CA1 region. Eur. J. Neurosci. 17, 1947-1952.

Joëls, M., and Baram, T. Z. (2009). The neuro-symphony of stress. Nat. Rev. Neurosci. 10, 459-466.

Joëls, M., Fernandez, G., and Roozendaal, B. (2011). Stress and emotional memory: a matter of timing. Trends Cogn. Sci. 15, 280-288.

Joëls, M., Pu, Z., Wiegert, O., Oitzl, M. S., and Krugers, H. J. (2006). Learning under stress: how does it work? Trends Cogn. Sci. 10, 152-158.

Karst, H., Berger, S., Erdmann, G. Schütz, G., and Joëls, M. (2010) Metaplasticity of amygdalar responses to the stress hormone corticosterone. Proc. Natl. Acad. Sci. U.S.A. 107, 14449-14454.

Karst, H., Berger, S., Turiault, M., Tronche, F., Schütz, G., and Joëls, M. (2005). Mineralocorticoid receptors are indispensable for nongenomic 
modulation of hippocampal glutamate transmission by corticosterone. Proc. Natl. Acad. Sci. U.S.A. 102, 19204-19207.

Karst, H., and Joëls, M. (2005). Corticosterone slowly enhances miniature excitatory postsynaptic current amplitude in mice CAl hippocampal cells. J. Neurophysiol. 94, 3479-3486.

Kauer, J. A., and Malenka, R. C. (2006). LTP: AMPA receptors trading places. Nat. Neurosci. 9, 593-594.

Keinanen, K., Wisden, W., Sommer, B., Werner, P., Herb, A., Verdoorn, T. A., Sakmann, B., and Seeburg, P. H. (1990). A family of AMPAselective glutamate receptors. Science $249,556-560$.

Kennedy, M. J., and Ehlers, M. D. (2006). Organelles and trafficking machinery for postsynaptic plasticity. Annu. Rev. Neurosci. 29, 325-362.

Kessels, H. W., and Malinow, R. (2009). Synaptic AMPA receptor plasticity and behaviour. Neuron 61, 340-350.

Kim, J. J., and Diamond, D. M. (2002). The stressed hippocampus, synaptic plasticity and lost memories. Nat. Rev. Neurosci. 3, 453-462.

LeDoux, J. E. (2000). Emotion circuits in the brain. Annu. Rev. Neurosci. 23, 155-184.

Kindt, M., Soeter, M., and Vervliet, B. (2009). Beyond extinction: erasing human fear responses and preventing the return of fear. Nat. Neurosci. $12,256-258$.

Kirschbaum, C., Pirke, K. M., and Hellhammer, D. H. (1993). The trier social stress test'-a tool for investigating psychobiological stress responses in a laboratory setting. Neuropsychobiology 28, 76-81.

Krugers, H. J., Hoogenraad, C. C., and Groc, L. (2010). Stress hormones and AMPA receptor trafficking in synaptic plasticity and memory. Nat. Rev. Neurosci. 11, 675-681.

Kuehl, L. K., Lass-Henneman, J., Richte, S., Blumenthal, T. D., Oitzl, M., and Schächinger, H. (2010). Accelerated trace eyeblink conditioning after cortisol IV-infusion. Neurobiol. Learn. Mem. 94, 547-553.

Laxmi, T. R., Stork, O., and Pape, H. C. (2003). Generalisation of conditioned fear and its behavioural expression in mice. Behav. Brain Res. $145,89-98$.

Lee, H. J., Berger, S. Y., Stiedl, O., Spiess, J., and Kim, J. J. (2001). Post-training injections of catecholaminergic drugs do not modulate fear conditioning in rats and mice. Neurosci. Lett. 303, 123-126.

Lee, H. K., Barbarosie, M., Kameyama, K., Bear, M. F., and Huganir, R. L.
(2000). Regulation of distinct AMPA receptor phosphorylation sites during bidirectional synaptic plasticity. Nature 405, 955-959.

Lisman, J. E., and Zhabotinsky, A. M. (2001). A model of synaptic memory: a CaMKII/PP1 switch that potentiates transmission by organizing an AMPA receptor anchoring assembly. Neuron 31, 191-201.

Liu, W., Yuen, E. Y., and Yan, Z. (2010). The stress hormone corticosterone increases synaptic alpha-amino-3hydroxy-5-methyl-4-isoxazolepropionic acid (AMPA) receptors via serum- and glucocorticoidinducible kinase (SGK) regulation of the GDI-Rab4 complex. J. Biol. Chem. 285, 6101-6108.

Lledo, P. M., Hjelmstad, G. O., Mukherji, S., Soderling, T. R., Malenka, R. C., and Nicoll, R. A. (1995). Calcium/calmodulindependent kinase II and long-term potentiation enhance synaptic transmission by the same mechanism. Proc. Natl. Acad. Sci. U.S.A. 92, 11175-11179.

Lu, J., Helton, T. D., Blanpied, T. A., Rácz, B., Newpher, T. M., Weinberg, R. J., and Ehlers, M. D. (2007). Postsynaptic positioning of endocytic zones and AMPA receptor cycling by physical coupling of dynamin-3 to Homer. Neuron 55, 874-889.

Maggio, N., and Segal, M. (2007). Striking variations in corticosteroid modulation of long-term potentiation along the septotemporal axis of the hippocampus. J. Neurosci. 27, 5757-5765.

Maggio, N., and Segal, M. (2009). Differential corticosteroid modulation of inhibitory synaptic currents in the dorsal and ventral hippocampus. J. Neurosci. 2, 2857-2866.

Makino, H., and Malinow, R. (2009). AMPA receptor incorporation into synapses during LTP: the role of lateral movement and exocytosis. Neuron $64,381-390$

Malenka, R. C. (2003). Synaptic plasticity and AMPA receptor trafficking. Ann. N. Y. Acad. Sci. 1003, 1-11.

Malinow, R., and Malenka, R. C. (2002). AMPA receptor trafficking and synaptic plasticity. Annu. Rev. Neurosci. 25, 103-126.

Mammen, A. L., Kameyama, K. Roche, K. W., and Huganir, R. L. (1997). Phosphorylation of the alpha-amino-3-hydroxy-5methylisoxazole4-propionic acid receptor GluR1 subunit by calcium/ calmodulin-dependent kinase II. $J$. Biol. Chem. 272, 32528-32533.
Man, H. Y., Sekine-Aizawa, Y., and Huganir, R. L. (2007). Regulation of \{alpha\}-amino-3-hydroxy5-methyl-4-isoxazolepropionic acid receptor trafficking through PKA phosphorylation of the Glu receptor 1 subunit. Proc. Natl. Acad. Sci. U.S.A. 104, 3579-3584.

Martin, S., Henley, J. M., Holman, D., Zhou, M., Wiegert, O., van Spronsen, M., Joëls, M., Hoogenraad, C. C., and Krugers, H. J. (2009). Corticosterone alters AMPAR mobility and facilitates bidirectional synaptic plasticity. PLoS ONE 4, e4714. doi 10.1371/journal.pone.0004714

McGaugh, J. L. (2000). Memory - a century of consolidation. Science 287, 248-251.

McGaugh, J. L. (2004). The amygdala modulates the consolidation of memories of emotionally arousing experiences. Annu. Rev. Neurosci. 27, $1-28$.

Merz, C. J., Tabbert, K., Schweckendiek, J., Klucken, T., Vaitl, D., Stark, R. and Wolf, O. T. (2010). Investigating the impact of sex and cortisol on implicit fear conditioning with fMRI. Psychoneuroendocrinology 35 33-46.

Migues, P. V., Hardt, O., Wu, D. C., Gamache, K., Sacktor, T. C., Wang, Y. T., and Nader, K. (2010). PKMzeta maintains memories by regulating GluR2-dependent AMPA receptor trafficking. Nat. Neurosci. 13, 630-634.

Nader, K., Schafe, G. E., and Le Doux J. E. (2000). Fear memories require protein synthesis in the amygdala for reconsolidation after retrieval. Nature 406, 722-726.

Nees, F., Richter, S., Lass-Henneman, J., Blumenthal, T. D., and Schächinger, H. (2008). Psychopharmacology 199 , 183-190.

Neves, G., Cooke, S. F., and Bliss, T. V. (2008). Synaptic plasticity, memory and the hippocampus: a neural network approach to causality. Nat. Rev. Neurosci. 2008 9, 65-75.

Newpher, T. M., and Ehlers, M. D. (2008). Glutamate receptor dynamics in dendritic microdomains. Neuron 58, 472-497.

Nicoll, R. A., Tomita, S., and Bredt, D. S. (2006). Auxiliary subunits assist AMPA-type glutamate receptors. Science 311, 1253-1256.

Nowak, L., Bregestovski, P., Ascher, P., Herbet, A., and Prochiantz, A. (1984). Magnesium gates glutamate-activated channels in mouse central neurones. Nature 307 , 462-465.

Oitzl, M. S., and de Kloet, E. R. (1992). Selective corticosteroid antagonists modulate specific aspects of spatial orientation learning. Behav. Neurosci. 106, 62-71.

Oitzl, M. S., Reichardt, H. M., Joëls, M., and de Kloet, E. R. (2001). Point mutation in the mouse glucocorticoid receptor preventing DNA binding impairs spatial memory. Proc. Natl. Acad. Sci. U.S.A. 98, 12790-12795.

Olijslagers, J. E., de Kloet, E. R., Elgersma, Y., van Woerden, G. M., Joëls, M., and Karst, H. (2008). Rapid changes in hippocampal CAl pyramidal cell function via pre- as well as postsynaptic membrane mineralocorticoid receptors. Eur. J. Neurosci. 27, 2542-2550.

Oomen, C. A., Soeters, H., Audureau, N. Vermunt, L., van Hasselt, F. N., Manders, E. M., Joëls, M., Lucassen, P. J. and Krugers, H. (2010). Severe early life stress hampers spatial learning and neurogenesis, but improves hippocampal synaptic plasticity and emotional learning under highstress conditions in adulthood. $J$. Neurosci. 30, 6635-6645.

Orchinik, M., Murray, T. F., and Moore, F. L. (1991). A corticosteroid receptor in neuronal membranes. Science 252, 1848-1851.

Orr, S. P., Milad, M. R., Metzger, L. J., Lasko, N. B., Gilbertson, M. W., and ,Pitman, R. K. (2006). Effects of beta blockade, PTSD diagnosis, and explicit threat on the extinction and retention of an aversively conditioned response. Biol. Psychol. 73 , 262-271

Park, M., Penick, E. C., Edwards, J. G., Kauer, J. A., and Ehlers, M. D. (2004). Recycling endosomes supply AMPA receptors for LTP. Science 305 1972-1975.

Passafaro, M., Piech, V., and Sheng, M. (2001). Subunit-specific temporal and spatial patterns of AMPA receptor exocytosis in hippocampal neurons. Nat. Neurosci. 4, 917-926.

Peskind, E. R., Wingerson, D., Murray, S., Pascualy, M., Dobie, D. J., Le Corre, P., Le Verge, R., Veith, R. C., and Raskind, M. A. (1995). Effects of Alzheimer's disease and norma aging on cerebrospinal fluid norepinephrine responses to yohimbine and clonidine. Arch. Gen. Psychiatry 52, 774-782.

Petrini, E. M., Lu, J., Cognet, L., Lounis, B., Ehlers, M. D., and Choquet, D. (2009). Endocytic trafficking and recycling maintain a pool of mobile surface AMPA receptors required for synaptic potentiation. Neuron 16, 92-105.

Pitman, R. K., and Delahanty, D. L. (2005). Conceptually driven pharmacologic approaches to acute trauma. CNS Spectr. 10, 99-106. 
Pitman, R. K., Milad, M. R., Igoe, S. A., Vangel, M. G., Orr, S. P., Tsareva, A. and Gamache, K, Nader, K. (2011). Systemic mifepristone blocks reconsolidation of cue-conditioned fear; propranolol prevents this effect. Behav. Neurosci. 125, 632-638.

Pitman, R. K., Sanders, K. M., Zusman, R. M., Healy, A. R., Cheema, F., Lasko, N. B., Cahill, L., and Orr, SP. (2002). Pilot study of secondary prevention of posttraumatic stress disorder with propranolol. Biol. Psychiatry 51, 189-192.

Plant, K., Pelkey, K. A., Bortolotto, Z. A., Morita, D., Terashima, A., McBain, C. J., Collingridge, G. L., and Isaac, J. T. (2006). Transient incorporation of native GluR2-lacking AMPA receptors during hippocampal longterm potentiation. Nat. Neurosci. 9 , 602-604.

$\mathrm{Pu}, \mathrm{Z}$., Krugers, H. J., and Joëls, M. (2007). Corticosterone time-dependently modulates betaadrenergic effects on long-term potentiation in the hippocampal dentate gyrus. Learn. Mem. 14, 359-367.

Pugh, C. R., Fleshner, M., and Rudy, J. W. (1997a). Type II glucocorticoid receptor antagonists impair contextual but not auditory-cue fear conditioning in juvenile rats. Neurobiol. Learn. Mem. 67, 75-79.

Pugh, C. R., Tremblay, D., Fleshner, M., and Rudy, J. W. (1997b). A selective role for corticosterone in contextualfear conditioning. Behav. Neurosci. 111, 503-511.

Reisel, D., Bannerman, D. M., Schmitt, W. B., Deacon, R. M., Flint, J., Borchardt, T., Seeburg, P. H., and Rawlins, J. N. (2002). Spatial memory dissociations in mice lacking GluR1. Nat. Neurosci. 5, 868-873.

Roche, K. W., O’Brien, R. J., Mammen, A. L., Bernhardt, J., and Huganir, R. L. (1996). Characterization of multiple phosphorylation sites on the AMPA receptor GluR1 subunit. Neuron 16, 1179-1188.

Rodrigues, S. M., LeDoux, J. E., and Sapolsky, R. M. (2009). The influence of stress hormones on fear circuitry. Annu. Rev. Neurosci. 32, 289 -313 .

Rogan, M. T., Stäubli, U. V., and LeDoux, J. E. (1997). Fear conditioning induces associative long-term potentiation in the amygdala. Nature 390, 604-607.

Roozendaal, B., Hernandez, A., Cabrera, S. M., Hagewoud, R., Malvaez, M., Stefanko, D. P., Haettig, J., and Wood, M. A. (2010). Membrane-associated glucocorticoid activity is necessary for modulation of long-term memory via chromatin modification. $J$. Neurosci. 30, 5037-5046.

Roozendaal, B., McEwen, B. S., and Chattarji, S. (2009). Stress, memory and the amygdala. Nat. Rev. Neurosci. 10, 423-433.

Roozendaal, B., Okuda, S., Van der Zee, E. A., and McGaugh, J. L. (2006). Glucocorticoid enhancement of memory requires arousalinduced noradrenergic activation in the basolateral amygdala. Proc. Natl. Acad. Sci. U.S.A. 103, 6741-6676.

Roozendaal, B., Schelling, G., and McGaugh, J. L. (2008). Corticotropin-releasing factor in the basolateral amygdala enhances memory consolidation via an interaction with the beta-adrenoceptor-cAMP pathway: dependence on glucocorticoid receptor activation. J. Neurosci. 28 6642-6651.

Rumpel, S., LeDoux, J., Zador, A., and Malinow, R. (2005). Postsynaptic receptor trafficking underlying a form of associative learning. Science 308, 83-88.

Sanderson, D. J., Good, M. A., Skelton, K., Sprengel, R., Seeburg, P. H., Rawlins, J. N., and Bannerman, D. M. (2009). Enhanced long-term and impaired short-term spatial memory in GluAl AMPA receptor subunit knockout mice: evidence for a dual-process memory model. Learn. Mem. 16, 379-386.

Sanderson, D. J., Gray, A., Simon, A. Taylor, A. M., Deacon, R. M., Seeburg, P. H., Sprengel, R., Good, M. A., Rawlins, J. N., and Bannerman, D. M. (2007). Deletion of glutamate receptor-A (GluR-A) AMPA receptor subunits impairs one-trial spatial memory. Behav. Neurosci. 121, 559-569.

Sanderson, D. J., Hindley, E., Smeaton, E., Denny, N., Taylor, A., Barkus, C., Sprengel, R., Seeburg, P. H., and Bannerman, D. M. (2011). Deletion of the GluAl AMPA receptor subunit impairs recency-dependent object recognition memory. Learn. Mem. 18, 181-190.

Sandi, C., and Rose, S. P. (1994) Corticosterone enhances long-term retention in one-day-old chicks trained in a weak passive avoidance learning paradigm. Brain Res. 647, 106-112.

Sangha, S., Scheibenstock, A., and Lukowiak, K. (2003). Reconsolidation of a long-term memory in lymnaea requires new protein and RNA synthesis and the soma of right pedal dorsal 1. J. Neurosci. 23, 8034-8040.
Schiller, D., Monfils, M. H., Raio, C. M., Johnson, D. C., Ledoux, J. E. and Phelps, E. A. (2010). Preventing the return of fear in humans using reconsolidation update mechanisms. Nature 463, 49-53.

Schmitt, W. B., Sprengel, R., Mack, V. Draft, R. W., Seeburg, P. H., Deacon, R. M., Rawlins, J. N., and Bannerman, D. M. (2005). Restoration of spatial working memory by genetic rescue of GluR-A-deficient mice. Nat. Neurosci. 8, 270-272.

Segal, M., Richter-Levin, G., and Maggio, N. (2010). Stress-induced dynamic routing of hippocampal connectivity: a hypothesis. Hippocampus 20, 1332-1338.

Shepherd, J. D., and Huganir, R. L. (2007). The cell biology of synaptic plasticity: AMPA receptor trafficking. Annu. Rev. Cell Dev. Biol. 23 613-643.

Shi, S., Hayashi, Y., Esteban, J. A. and Malinow, R. (2001). Subunitspecific rules governing AMPA receptor trafficking to synapses in hippocampal pyramidal neurons. Cell 105, 331-343.

Shimshek, D. R., Jensen, V., Celikel, T., Geng, Y., Schupp, B., Bus, T. Mack, V., Marx, V., Hvalby, Ø., Seeburg, P. H., and Sprengel, R. (2006). Forebrain-specific glutamate receptor B deletion impairs spatial memory but not hippocampal field longterm potentiation. J. Neurosci. 26, 8428-8440.

Soeter, M., and Kindt, M. (2010). Dissociating response systems: erasing fear from memory. Neurobiol. Learn. Mem. 94, 30-41.

Soeter, M., and Kindt, M. (2011a). Noradrenergic enhancement of associative fear memory in humans. Neurobiol. Learn. Mem. 96, 263-271.

Soeter, M., and Kindt, M. (2011b). Disrupting reconsolidation: pharmacological and behavioral manipulations. Learn. Mem. 18, 357-366.

Soeter, M., and Kindt, M. (2011c). Noradrenergic strengthening of fear memory impairs extinction learning but not disrupting reconsolidation.

Southwick, S. M., Davis, M., Horner B., Cahill, L., Morgan, C. A., Gold, P. E., Bremner, J. D., and Charney, D. C. (2002). Relationship of enhanced norepinephrine activity during memory consolidation to enhanced long-term memory in humans. Am. J. Psychiatry 159, 1420-1422.

Stark, R., Wolf, O. T., Tabbert, K. Kagerer, S., Zimmermann, M. Kirsch, P., Schienle, A., and Vaitl, D. (2006). Influence of the stress hormone cortisol on fear conditioning in humans: evidence for sex difference in the response of the prefrontal cortex. Neuroimage 32, 1290-1298.

Tabbert, K., Merz, C. J., Klucken, T. Schweckendiek, J., Vaitl, D., Wolf, O. T., and Stark, R. (2010). Cortisol enhances neural differentiation during fear acqusition and extinction in contingency aware young women. Neurobiol. Learn. Mem. 94 , 392-401.

Tanabe, Y., Masu, M., Ishii, T., Shigemoto, R., and Nakanishi, S. (1992). A family of metabotropic glutamate receptors. Neuron 8, 169-179.

Tenorio, G., Connor, S. A., Guévremont, D., Abraham, W. C., Williams, J., O'Dell, T. J., and Nguyen, P. V. (2010). "Silent" priming of translation-dependent LTP by $B$ adrenergic receptors involves phosphorylation and recruitment of AMPA receptors. Learn. Mem. 23, 627-638.

Thomas, M. J., Moody, T. D., Makhinson, M., and O'Dell, T. J. (1996). Activity-dependent beta-adrenergic modulation of low frequency stimulation induced LTP in the hippocampal CA1 region. Neuron 17 475-482.

Van Stegeren, A. H. (2008). The role of the noradrenergic system in emotional memory. Acta Psychol. (Amst.) $127,532-541$

Van Stegeren, A. H., Everaerd, W., Cahill, L., McGaugh, J. L., and Gooren, L. J. G. (1998). Memory for emotional events: differential effects of centrally versus peripherally acting Bblocking agents. Psychopharmacology (Berl.) 138, 305-310.

Venero, C., and Borrell, J. (1999). Rapid glucocorticoid effects on excitatory amino acid levels in the hippocampus: a microdialysis study in freely moving rats. Eur. J. Neurosci. 11, 2465-2473.

Wang, W., Zhu, W., Wang, S., Yang, D., Crow, M. T., Xiao, R. P., and Cheng, H. (2004). Sustained betal-adrenergic stimulation modulates cardiac contractility by $\mathrm{Ca} 2+/$ calmodulin kinase signaling pathway. Circ. Res. 95 798-806.

Weaver, I. C., Meaney, M. J., and Szyf, M. (2006). Maternal care effects on the hippocampal transcriptome and anxiety-mediated behaviors in the offspring that are reversible in adulthood. Proc. Natl. Acad. Sci. U.S.A 103, 3480-3485.

Wenthold, R. J., Petralia, R. S., Blahos, J. II, and Niedzielski, A. S. (1996). Evidence for multiple AMPA receptor complexes in hippocampal CA1/CA2 neurons. J. Neurosci. 16, 1982-1989. 
Whitlock, J. R., Heynen, A. J., Shuler, M. G., and Bear, M. F. (2006). Learning induces long-term potentiation in the hippocampus. Science 313, 1093-1097.

Wiegert, O., Joëls, M., and Krugers, H. (2006). Timing is essential for rapid effects of corticosterone on synaptic potentiation in the mouse hippocampus. Learn. Mem. 13, 110-113.

Wiegert, O., Pu, Z., Shor, S., Joëls, M., and Krugers, H. (2005). Glucocorticoid receptor activation selectively hampers N-methylD-aspartate receptor dependent hippocampal synaptic plasticity in vitro. Neuroscience 135, 403-411.

Winder, D. G., Martin, K. C., Muzzio, I. A., Rohrer, D., Chruscinski, A., Kobilka, B., and Kandel, E. R. (1999). ERK plays a regulatory role in induction of LTP by theta frequency stimulation and its modulation by betaadrenergic receptors. Neuron 24, 715-726.

Wisden, W., and Seeburg, P. H. (1993). Mammalian ionotropic glutamate receptors. Curr. Opin. Neurobiol. 3 , 291-298.
Wolf, O. T. (2009). Stress and memory in humans: twelve years of progress? Brain Res. 1293, 142-154.

Wolf, O. T., Minnebusch, D., and Daum, I. (2009). Stress impairs acqusition of delay eyeblink conditioning in men and women. Neurobiol. Learn. Mem. 91, 431-436.

$\mathrm{Xu}, \mathrm{L} .$, Anwyl, R., and Rowan, M. J. (1997). Behavioural stress facilitates the induction of long-term depression in the hippocampus. Nature 387, 497-500.

Yuen, E. Y., Liu, W., Karatsoreos, I. N., Feng, J., McEwen, B. S., and Yan, Z. (2009). Acute stress enhances glutamatergic transmission in prefrontal cortex and facilitates working memory. Proc. Natl. Acad. Sci. U.S.A. 106, 14075-14079.

Yuen, E. Y., Liu, W., Karatsoreos, I. N., Ren, Y., Feng, J., McEwen, B. S., and Yan, Z. (2011). Mechanisms for acute stress-induced enhancement of glutamatergic transmission and working memory. Mol. Psychiatry 16, 156-170.

Zamanillo, D., Sprengel, R., Hvalby, O., Jensen, V., Burnashev, N., Rozov, A., Kaiser, K. M., Köster, H. J.,
Borchardt, T., Worley, P., Lübke, J., Frotscher, M., Kelly, P. H., Sommer, B., Andersen, P., Seeburg, P. H., and Sakmann, B. (1999). Importance of AMPA receptors for hippocampal synaptic plasticity but not for spatial learning. Science 284, 1805-1811.

Zhou, M., Bakker, E. H., Velzing, E. H., Berger, S., Oitzl, M., Joëls, M., and Krugers, H. J. (2010). Both mineralocorticoid and glucocorticoid receptors regulate emotional memory in mice. Neurobiol. Learn. Mem. 94, 530-537.

Zhou, M., Hoogenraad, C. C., Joels, M., and Krugers, H. J. (2011). Combined $\beta$-adrenergic and corticosteroid receptor activation regulates AMPA receptor function in hippocampal neurons. J. Psychopharmacol. (in press).

Zorawski, M., Blanding, N. Q., Kuhn, C. M., and LaBar, K. S. (2006). effects of stress and sex on acqusition and consolidation of human fear conditioning. Learn. Mem. 13, 441-450.

Zorawski, M., Cook, C. A., Kuhn, C. M., and LaBar, K. S. (2005). Sex, stress, and fear: individual differences in conditioned learning. Cogn. Affect Behav. Neurosci. 5, 191-201.

Conflict of Interest Statement: The authors declare that the research was conducted in the absence of any commercial or financial relationships that could be construed as a potential conflict of interest.

Received: 28 May 2011; paper pending published: 16 June 2011; accepted: 05 September 2011; published online: 11 October 2011.

Citation: Krugers HJ, Zhou M, Joëls $M$ and Kindt $M$ (2011) Regulation of excitatory synapses and fearful memories by stress hormones. Front. Behav. Neurosci. 5:62. doi: 10.3389/fnbeh.2011.00062 Copyright (c) 2011 Krugers, Zhou, Joëls and Kindt. This is an open-access article subject to a non-exclusive license between the authors and Frontiers Media $S A$, which permits use, distribution and reproduction in other forums, provided the original authors and source are credited and other Frontiers conditions are complied with. 